\title{
Evaluation of in situ measurements of atmospheric carbon monoxide at Mount Waliguan, China
}

\author{
F. Zhang ${ }^{1,2}$, L. X. Zhou ${ }^{1}$, P. C. Novelli ${ }^{3}$, D. E. J. Worthy ${ }^{4}$, C. Zellweger ${ }^{5}$, J. Klausen ${ }^{6}$, M. Ernst ${ }^{4}$, M. Steinbacher ${ }^{5}$, \\ Y. X. Cai ${ }^{7}$, L. Xu ${ }^{1}$, S. X. Fang ${ }^{1}$, and B. Yao ${ }^{1}$ \\ ${ }^{1}$ Chinese Academy of Meteorological Sciences (CAMS), CMA, Beijing 100081, China \\ ${ }^{2}$ Graduate University of Chinese Academy of Sciences, Beijing 100049, China \\ ${ }^{3}$ Earth System Research Laboratory, National Oceanic and Atmospheric Administration, Boulder, CO, USA \\ ${ }^{4}$ Environment Canada, 4905 Dufferin Street, Toronto, Ont., M3H 5T4, Canada \\ ${ }^{5}$ Empa, Swiss Federal Laboratories for Materials Science and Technology, Ueberlandstrasse 129, \\ 8600 Duebendorf, Switzerland \\ ${ }^{6}$ Federal Department of Home Affairs FDHA, Federal Office of Meteorology and Climatology MeteoSwiss, \\ Kraehbuehlstrasse 58, P.O. Box 514, 8044 Zuerich, Switzerland \\ ${ }^{7}$ Qinghai Meteorological Bureau, CMA, Xining 810001, China
}

Received: 9 October 2010 - Published in Atmos. Chem. Phys. Discuss.: 20 January 2011

Revised: 25 May 2011 - Accepted: 27 May 2011 - Published: 1 June 2011

\begin{abstract}
Quasicontinuous measurements of carbon monoxide (CO) recorded over three years at Mount Waliguan (WLG), a global baseline station in remote western China, were examined using back trajectory analysis. The data include a revision to correct the working reference scale to the WMO2000 scale and corrections for drift in the reference gases. Between July 2004 and June 2007, CO exhibited large fluctuations and the 5\%,50\% and 95\%-percentiles of relevant $\mathrm{CO}$ mixing ratios were $102 \mathrm{ppb}, 126 \mathrm{ppb}$ and $194 \mathrm{ppb}$. Approximately $50 \%$ of all observed data were selected as $\mathrm{CO}$ background data using a mathematical procedure of robust local regression, with the remainder affected by regional-scale pollution. The monthly mean background CO mixing ratios showed a minimum in summer and a maximum in late winter, although all seasons were affected by short-term enhancements that exceeded background levels. The CO data were compared to values observed at the high alpine research station at Jungfraujoch, Switzerland. Smaller seasonal amplitudes were observed at WLG compared to the Jungfraujoch due to lower winter and spring $\mathrm{CO}$ levels, however, episodic enhancements of polluted air were greater at WLG. The air parcels arriving at WLG came predominately from the west, except in summer when advection
\end{abstract}

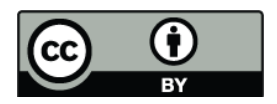

Correspondence to: L. X. Zhou (zhoulx@cams.cma.gov.cn) from the east and southeast prevailed. Transport from the east or southeast typically brought polluted air to the site, having passed over populated urban areas upwind. A large number of elevated $\mathrm{CO}$ mixing ratios could also be associated with advection from the northwest of WLG via the central Xinjiang Uygur Autonomous Region (XUAR) and the Ge'ermu urban area where growing industrial activities as well as crops residue burning provide sources of CO. Air masses passing over northwestern Gansu were associated with relatively high $\mathrm{CO}$ values suggesting an anthropogenic influence, which was likely due to anthropogenic emissions from northwestern China (based on back-trajectory and potential source contribution analysis and on the INTEX-B: intercontinental Chemical Transport Experiment-Phase B). Background conditions were observed most frequently in air parcels from remote Tibet west of WLG. The probability that air parcels pass over regions of clean or polluted regions was further identified using potential source contribution function (PSCF) analysis.

\section{Introduction}

Carbon monoxide (CO) affects the tropospheric oxidizing capacity as it is the main sink of the hydroxyl radical $(\mathrm{OH})$ (Logan et al., 1981; Thompson, 1992). Through its role in removing $\mathrm{OH}, \mathrm{CO}$ has been identified as an important indirect

Published by Copernicus Publications on behalf of the European Geosciences Union. 
greenhouse gas (Daniel and Solomon, 1998). With an atmospheric lifetime ranging from 10 days in summer over continental regions to more than a year over polar regions in winter (Novelli et al., 1992), the uneven distribution of sources causes large spatial and temporal $\mathrm{CO}$ variations.

The main sources of $\mathrm{CO}$ are associated with primary emissions from combustion processes (transport, heating, industrial activities and biomass burning) and the oxidation of methane and other hydrocarbons (e.g., Logan et al., 1981; Holloway et al., 2000).

A gas chromatographic technique combined with a mercuric oxide detector $(\mathrm{GC}-\mathrm{HgO})$ has been widely used in quasi-continuous measurements of $\mathrm{CO}$ mixing ratios at many locations over the globe because of its low detection limit and good precision (Novelli et al., 1992, 1998). However, the nonlinearity of the technique requires careful calibration. The drift of $\mathrm{CO}$ mixing ratios in standard gases over time may further affect the measurement accuracy (Novelli et al., 2003; Zellweger et al., 2009). As a result, the observed discrepancies between different labs during intercomparison activities have often exceeded the limits stated in the quality objectives of the World Meteorological Organization/Global Atmosphere Watch (WMO/GAW) (WMO, 2010) and have, to a certain extent, limited the accuracy of $\mathrm{CO}$ regional source and sink estimation from their spatial and temporal distributions. Although industrial growth in Asia has the potential to emit large amounts of $\mathrm{CO}$, there are few monitoring stations on the continent. The location of WLG is influenced both by background and polluted air, from which changes in regional CO abundance and sources can be examined. For the proper use of the WLG data it is essential to first evaluate the quality of the $\mathrm{CO}$ measurements and the calibration history.

In this paper, we first establish the link between the WLG measurements and the WMO2000 CO scale. We then characterize the $\mathrm{CO}$ time series in terms of background vs. polluted air parcels and compare the results with those observed at Jungfraujoch, Switzerland. Lastly, using two trajectorybased statistical approaches, we examine how the meteorological conditions and potential source regions influence WLG observation.

\section{Site description and experimental method}

\subsection{Description of the site}

Waliguan Baseline Observatory (WLG, $36.28^{\circ} \mathrm{N}, 100.09^{\circ} \mathrm{E}$, $3816 \mathrm{~m}$ a.s.1.), situated in remote western China (Fig. 1), is one of the $26 \mathrm{WMO} / \mathrm{GAW}$ global baseline stations. It is located at the edge of the northeastern part of the Tibetan Plateau and run by the China Meteorological Administration (CMA). The area surrounding the station is pristine with sparse vegetation, mostly arid and semiarid grassland. Small farms are located in the lower valley area, with yak and sheep

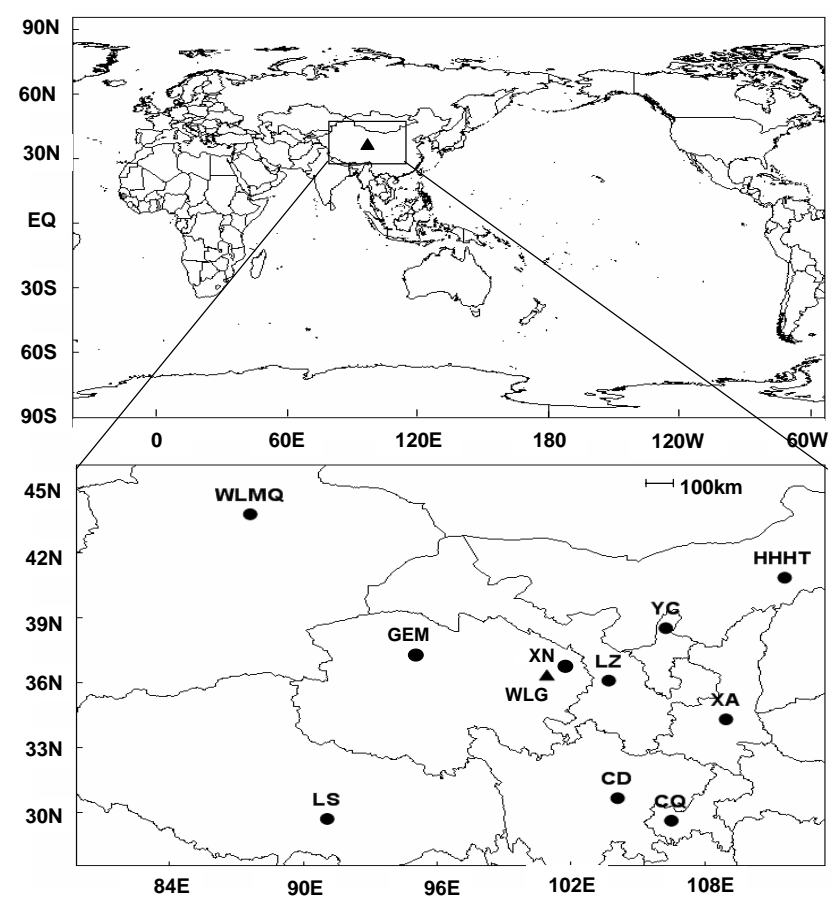

Fig. 1. Map of Waliguan (black triangle) and location of main cities (black dots): CD-Chengdu; CQ-Chongqing; GEMGe'ermu; HHHT-Huhehaote; LS-Lasa; LZ-Lanzhou; WLGWaliguan; WLMQ-Wulumuqi; XA-Xi'an; XN-Xining; YCYinchuan.

grazing during the summer months. Xining city lies approximately $90 \mathrm{~km}$ northeast of WLG with a total population of 2.2 million.

The predominant wind directions are southwest in winter and northeast/southeast in summer (Zhou et al., 2003). In-situ measurements of ambient $\mathrm{CO}_{2}$ and $\mathrm{CH}_{4}$ have been conducted since 1990s (Zhou et al., 2003, 2004), and quasicontinuous measurements of ambient CO at WLG started in 1997 (Zhou et al., 2001) and stopped in July 2007. However, discreet air samples are still collected weekly for $\mathrm{CO}$, $\mathrm{CO} 2$ and $\mathrm{CH} 4$ by the NOAA cooperative air sampling program (http://www.esrl.noaa.gov/gmd/ccgg/). Observations of these trace gases at WLG provide essential information on sources and sinks within the Eurasian continent because of its unique location (Zhou et al., 2005, 2006). Here we focus on measurements recorded from July 2004 to June 2007 to evaluate $\mathrm{CO}$ at WLG.

\subsection{Experimental methods}

\subsubsection{Instrumentation and analysis}

CO mixing ratios at WLG were measured using an RGA3 gas chromatograph (GC) equipped with an $\mathrm{HgO}$ reduction detector (Trace Analytical Inc.). The automated sampling module was designed to sample from separate gas 
streams (standard tanks and ambient air) supplied to the instrument. The ambient air was first pumped at approximately $51 \mathrm{~min}^{-1}$ by a KNF Neuberger N2202 vacuum pump via a dedicated $80 \mathrm{~m} 0.95 \mathrm{~cm}$ i.d. Dekabon tube sampling from the intake on an $89 \mathrm{~m}$ steel triangular tower located approximately $15 \mathrm{~m}$ away from the laboratory. The ambient air then passed through a bypass line to release excess pressure and keep the flow rate in the sample line at $11 \mathrm{~min}^{-1}$. The air was then filtered via a $7 \mu \mathrm{m}$ inline filter and dried to a dew point of $-65^{\circ} \mathrm{C}$. A bleed valve reduced the flow to approximately $0.231 \mathrm{~min}^{-1}$ before reaching the sampling loop. Flow through the $3 \mathrm{ml}$ sampling loop was stopped a few seconds before injection to equilibrate its pressure. The flow rate of the carrier gas $\left(\mathrm{N}_{2}, 99.999 \%\right)$ was $0.031 \mathrm{~min}^{-1}$. Entering the GC, the air sample first passed through a precolumn (Unibeads 1S 60/80 mesh) and thereafter into an analytical column (Molecular Sieve 5 $60 / 80$ mesh) maintained at $90^{\circ} \mathrm{C}$. The sample then passed into a reaction chamber $\left(265^{\circ} \mathrm{C}\right.$ ) where $\mathrm{CO}$ was oxidized to $\mathrm{CO}_{2}$ and $\mathrm{HgO}$ reduced to $\mathrm{Hg}\left(\mathrm{CO}+\mathrm{HgO}(\mathrm{s}) \rightarrow \mathrm{CO}_{2}+\mathrm{Hg}(\mathrm{g})\right)$; $\mathrm{Hg}$ was then detected by UV absorption. A HP3396 integrator acquired and processed the detector analog information. Peak height was used for $\mathrm{CO}$ quantification. Sixteen injections were made every hour including two reference gases. The hourly, daily and monthly averages were aggregated from 14 ambient air samples per hour (see Sect. 2.2.2). The overall precision, defined as the standard deviation of repeated calibration of three reference samples ( $\sim 100-300 \mathrm{ppb} \mathrm{CO})$, with 30 measurements per tank was $1.0-2.5 \mathrm{ppb}$. A schematic of the system and other details of the analysis have been described previously (Zhou et al., 2001)

During the period of study, no data were collected when new analytical columns and $\mathrm{HgO}$ beds were exchanged for the old ones. Other missing data resulted from periods of instrument calibration or, more commonly, instrument malfunction (e.g. problems with stream selection valves, which sometimes shifted to a wrong position). Those data have been flagged and are not included. During the period of study acceptable data were collected approximately $75 \%$ of the time.

\subsubsection{Standards and calibrations}

Both the absolute response and the instrument response curve can change over time using the $\mathrm{GC}-\mathrm{HgO}$ technique (Novelli et al., 1992). Therefore a calibration sequence using working low (WL, $100 \mathrm{ppb}$ ) and working high (WH, $290 \mathrm{ppb}$ ) reference gases was applied (WH followed by 7 air samples, WL followed by another 7 air samples). Ambient CO mixing ratios were determined by the updated linear curve of the WH and WL in each hour. Target tanks with assigned CO mixing ratios of $203.9 \mathrm{ppb}$ (July 2004-December 2004) and 254.9 ppb (January 2005-June 2007) were injected every six hours to track and evaluate the performance of the system (Fig. 2). Over the three year study $92 \%$ of the measurements

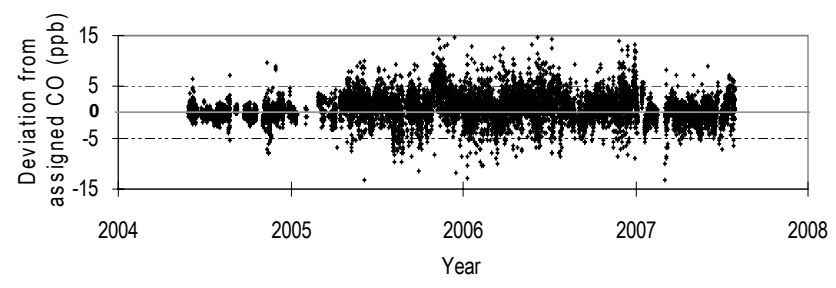

Fig. 2. Deviation of CO mixing ratios for target gases from their assigned value.

of the target tanks were within $\pm 5.0 \mathrm{ppb}$ of their assigned value, indicating good long-term system stability.

To account for non-linear instrument response, we used a weekly calibration sequence with working gases followed by a set of six laboratory primary standards (S1-S6, contained in 29.51 aluminum cylinders with $\mathrm{CO}$ ranging from 50 to $300 \mathrm{ppb}$, Table 1). The laboratory primary standards were calibrated in 1997 at Environment Canada (EC, formally the Meteorological Service of Canada, MSC) against standards referenced to the WMO1988 CO scale (Novelli et al., 1994a, b). Assigned $\mathrm{CO}$ mixing ratios for the working gases were updated every week using the quadratic fitting function derived from the six primary standards at WLG.

\subsection{Calibration scale conversions}

The CO reference scale maintained at National Oceanic and Atmospheric Administration/Earth System Research Laboratory (NOAA/ESRL) was designated by WMO as the reference scale for the GAW program. As the Central Calibration Laboratory (CCL) for GAW, NOAA provides calibrated standards to other laboratories. The certified values from the CCL were revised in 2002 to account for drift in the original WMO1988 scale and are denoted as WMO2000 (WMO, 2010).

Our six laboratory primary standards (S1-S6) were calibrated at EC against the original WMO1988 scale. After the EC standards were revised by the CCL in response to a WMO scale correction (Novelli et al., 2003), EC provided WLG with a conversion algorithm to update the WLG primary standards to WMO2000. The revised WLG CO mixing ratios were calculated using a quadratic conversion curve $\left(y=0.0002 \cdot x^{2}-0.1036 \cdot x+13.99, R^{2}=0.9856\right.$, where $x$ refers to CO mixing ratios in WLG working scale and $y$ is the difference of results (WMO2000 scale minus WLG working scale). The results are listed in Group 1 of Table 1.

We also used results from the WMO World Calibration Centre (WCC)-Empa CO audits in 2000 and 2004 at WLG to revise the WLG standards (Zellweger et al., 2000, 2004). In 2000, four cylinders from WCC were calibrated against working standards at WLG. Based on differences in the WLG and WCC results, a quadratic fit of $y=0.0002 \cdot x^{2}-0.1233 \cdot x+17.896\left(R^{2}=1\right.$, here $x$ refers to 
Table 1. S1-S6 lab primary standards cylinders revision for $\mathrm{CO}$ mixing ratios.

\begin{tabular}{lrrrrrr}
\hline Cylinder\# & CA01488 & CA01500 & CA01441 & CA01457 & CA01459 & CA01449 \\
\hline Used as & $\mathrm{S} 1$ & $\mathrm{~S} 2$ & $\mathrm{~S} 3$ & $\mathrm{~S} 4$ & $\mathrm{~S} 5$ & $\mathrm{~S} 6$ \\
Assigned (ppb) $^{\mathrm{a}}$ & 49.4 & 95.2 & 150.2 & 202 & 254.9 & 297.4 \\
Group $^{\mathrm{b}}$ & $58.8^{*}$ & $101.1^{*}$ & $153.1^{*}$ & $203.2^{*}$ & $255.5^{*}$ & $298.3^{*}$ \\
Group2 $^{\mathrm{c}}$ & $61.7^{*}$ & $103.2^{*}$ & $154.1^{*}$ & $203.2^{*}$ & 254.4 & 296.3 \\
Group3 $^{\mathrm{d}}$ & 59.0 & $103.9^{*}$ & $155.7^{*}$ & $205.5^{*}$ & $259.1^{*}$ & $298.5^{*}$ \\
Mean (see text) $_{\text {S.D. }}^{60.2}$ & 102.7 & 154.3 & 204.0 & 257.3 & 298.4 \\
Expanded Uncertainty & 2.1 & 1.4 & 1.3 & 1.3 & 2.6 & 0.2 \\
\hline
\end{tabular}

a WLG working scale, in ppb, assigned by MSC in 1997 against the WMO88 scale.

b WMO2000, in ppb, calculated based on the curves from EC.

c WMO2000, in ppb, calculated based on the data of WCC 2000 CO audit at WLG (CO span of WCC cylinders covering from 58.6 to 207.1 ppb).

d WMO2000, in ppb, calculated based on the data of WCC 2004 CO audit at WLG (Range of the 2004 audit gases from 73.4 to 304.5 ppb).

*Results used to assigned mixing ratios to the WLG standards. These are referenced to the WMO2000 scale.

CO mixing ratios in WLG working scale, $y$ is the estimated bias (WMO2000 scale minus WLG working scale) was applied to update the S1-S6 values. The results are shown in Table 1, Group 2. Because the CO values of WCC cylinders covered the range from 58.6 to $207.1 \mathrm{ppb}$, the function is more accurate and robust for calculating S1-S4; the results for S5 and S6 contain larger uncertainties and were not used in the revision.

We further tied the WLG working standards to the WMO2000 scale using the results of the WCC audit at WLG in 2004. Six WCC CO traveling standards (referenced toWMO2000 scale, covering the range 73.4 to $304.5 \mathrm{ppb}$ ) were used to re-calibrate the S1-S6 laboratory primary standards; in this case, the $\mathrm{CO}$ mixing ratios of the S1-S6 cylinders were regarded as unknown. We use the assigned values of the six WCC cylinders to calculate CO values of S1-S6. The results of these on-site calibrations are shown in Table 1, Group 3. We only used results (marked with an asterisk in Table 1) that fell within the range of $\mathrm{CO}$ mixing ratios in these transfer gases to assurance accurate measurements of ambient $\mathrm{CO}$ mixing ratios due to the instrument non-linear response of $\mathrm{GC}-\mathrm{HgO}$. Then the ambient $\mathrm{CO}$ mixing ratios were updated and recalculated using the newly assigned $\mathrm{CO}$ mixing ratios.

In summary, the CO mixing ratios for the six WLG working standards were revised based upon results from the reanalysis by EC and the two WCC audits. Ambient CO measurements were revised based on the corrected working standards. All the results are reported on the WMO2000 scale.

\section{Results and discussions}

\subsection{Revised CO data}

New calibration functions were generated using the revised $\mathrm{CO}$ mixing ratios of the S1-S6 references. These functions

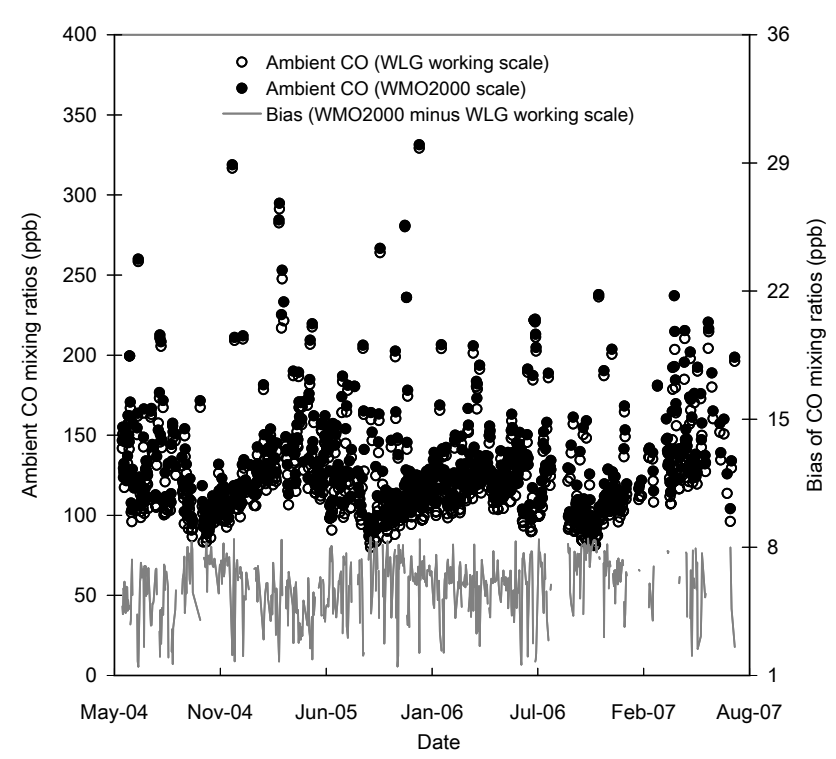

Fig. 3. Overlay of the revised (black dots) and original (white circles) daily averages of $\mathrm{CO}$; the gray line shows the bias of the original data which indicates a bias of the WLG working scale relative to the WMO2000 scale.

were then used to re-process ambient $\mathrm{CO}$ mixing ratios. Figure 3 displays an overlay of the original and the revised daily averages of the ambient $\mathrm{CO}$ mixing ratios. As can be seen in Table 1, the largest correction to the original standard CO assignments occurred at the lower end of the scale. Therefore, as the levels of ambient $\mathrm{CO}$ varied, the magnitude of the correction to the ambient samples changed accordingly. Changes in $\mathrm{CO}$ were typically greatest in samples with a lower mixing ratio (7-8 ppb below $100 \mathrm{ppb})$ and decreased to $2 \mathrm{ppb}$ at $200 \mathrm{ppb}$ (Fig. 4). 


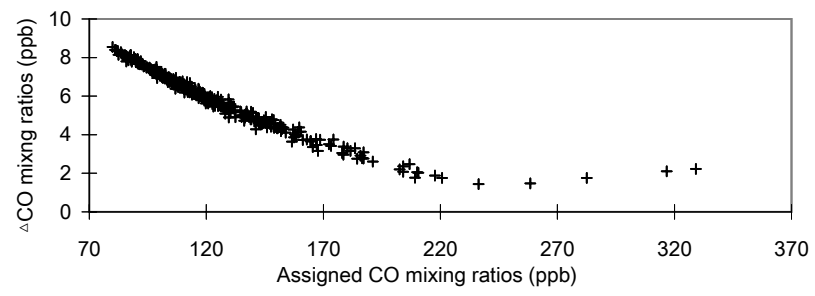

Fig. 4. Ambient CO: WMO2000 minus WLG working scale.

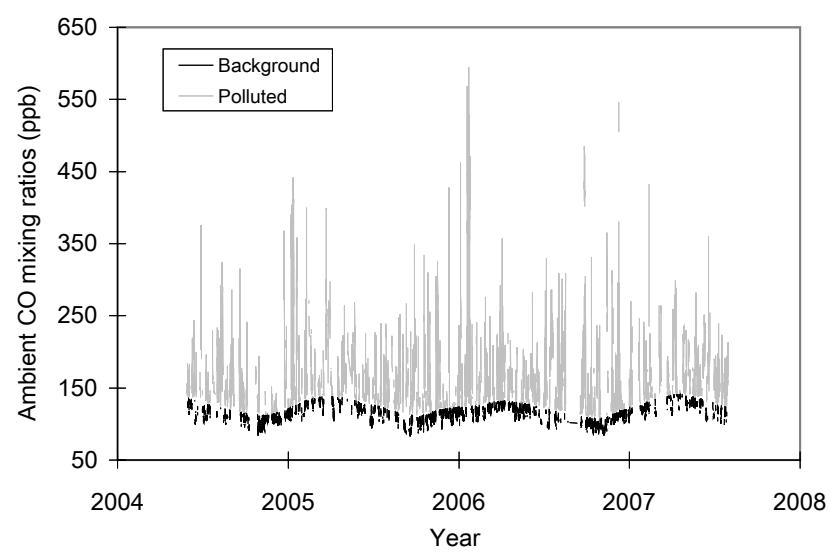

Fig. 5. Ambient $\mathrm{CO}$ mixing ratios obtained from in situ measurement (hourly averages, black lines represent background conditions, and gray lines represent data influenced by polluted air masses) at WLG (July 2004-June 2007).

\subsection{Time series and monthly variations}

Figure 5 shows the hourly data of $\mathrm{CO}$ at WLG from July 2004 to June 2007. Enhanced CO mixing ratios were observed with some episodes exceeding $200 \mathrm{ppb}$, and back trajectories for the specific periods of high $\mathrm{CO}$ have traced these episodes to regions with large sources (see next section). To define $\mathrm{CO}$ mixing ratios representing regional background air, we used a statistical approach for extracting background concentrations from measurements. This method is based on robust local regression called REBS (robust extraction of background signal). It is a modified version of a technique of robust baseline estimation (RBE) and developed for baseline removal from chemical analytical spectra (Ruckstuhl et al., 2001, 2010). The REBS is a purely nonparametric technique that is used to follow any long-term trend and seasonal variation (Ruckstuhl et al., 2010). It assumes that the background signal varies very slowly relative to contributions of the regional signal; the measurement errors are independent and Gaussian-distributed with mean 0 . These assumptions are suitable to WLG where the variation of the baseline signal is on the order of weeks and the regional signal is hourly to daily. The measurement errors are expected to be random. Approximately $50 \%$ of all observed $\mathrm{CO}$ data were thus classified as background data. The

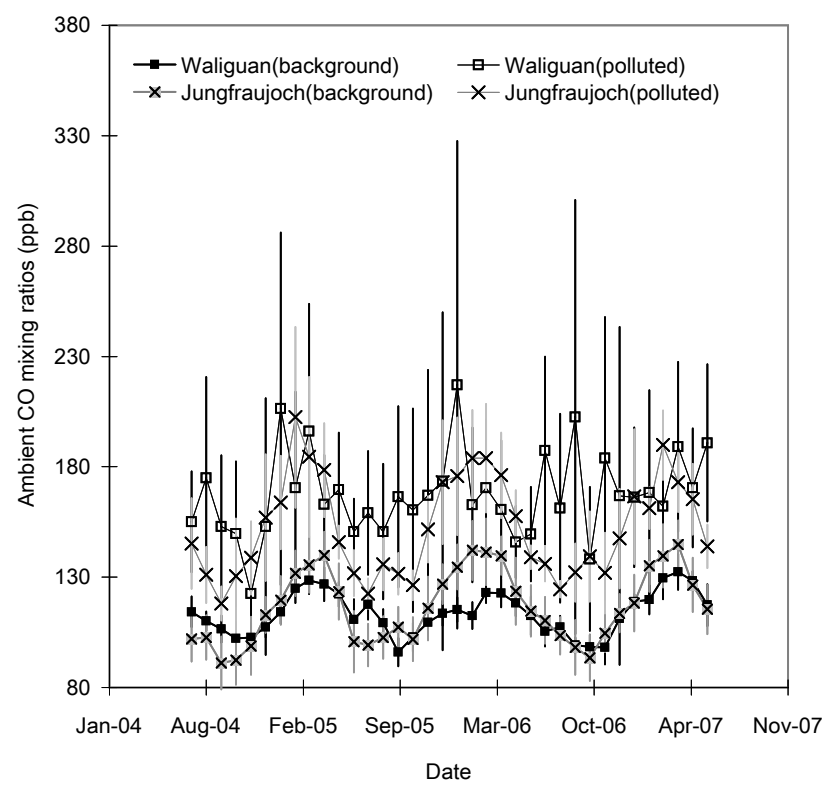

Fig. 6. Monthly mean mixing ratios of ambient $\mathrm{CO}$ and its standard deviations at Waliguan and Jungfraujoch for both air identified as background and as polluted.

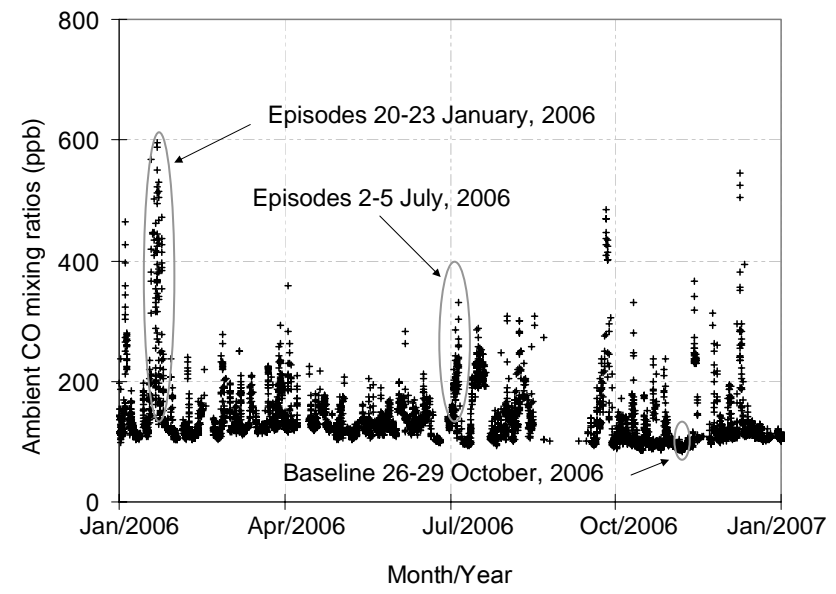

Fig. 7. Hourly data of ambient CO for the whole year of 2006.

distribution of $\mathrm{CO}$ mixing ratios is characterized by value of $102 \mathrm{ppb}, 126 \mathrm{ppb}$ and $194 \mathrm{ppb}$ for the $5 \%, 50 \%$ and $95 \%$ percentile. Data classified as background (Fig. 5) exhibited low mixing ratios and smooth changes; data classified as pollution-influenced typically exhibit higher $\mathrm{CO}$ with large fluctuations compared to regional background values.

To investigate regional influences on mixing ratios of $\mathrm{CO}$ observed at WLG, we compared both background and pollution values with data from the Jungfraujoch, Switzerland $\left(46.55^{\circ} \mathrm{N}, 7.99^{\circ} \mathrm{E}, 3580 \mathrm{~m}\right.$ a.s.l.) another mountain-top station impacted by regional-scale pollution (Fig. 6). The Jungfraujoch (JFJ), situated in Central Europe, is influenced 


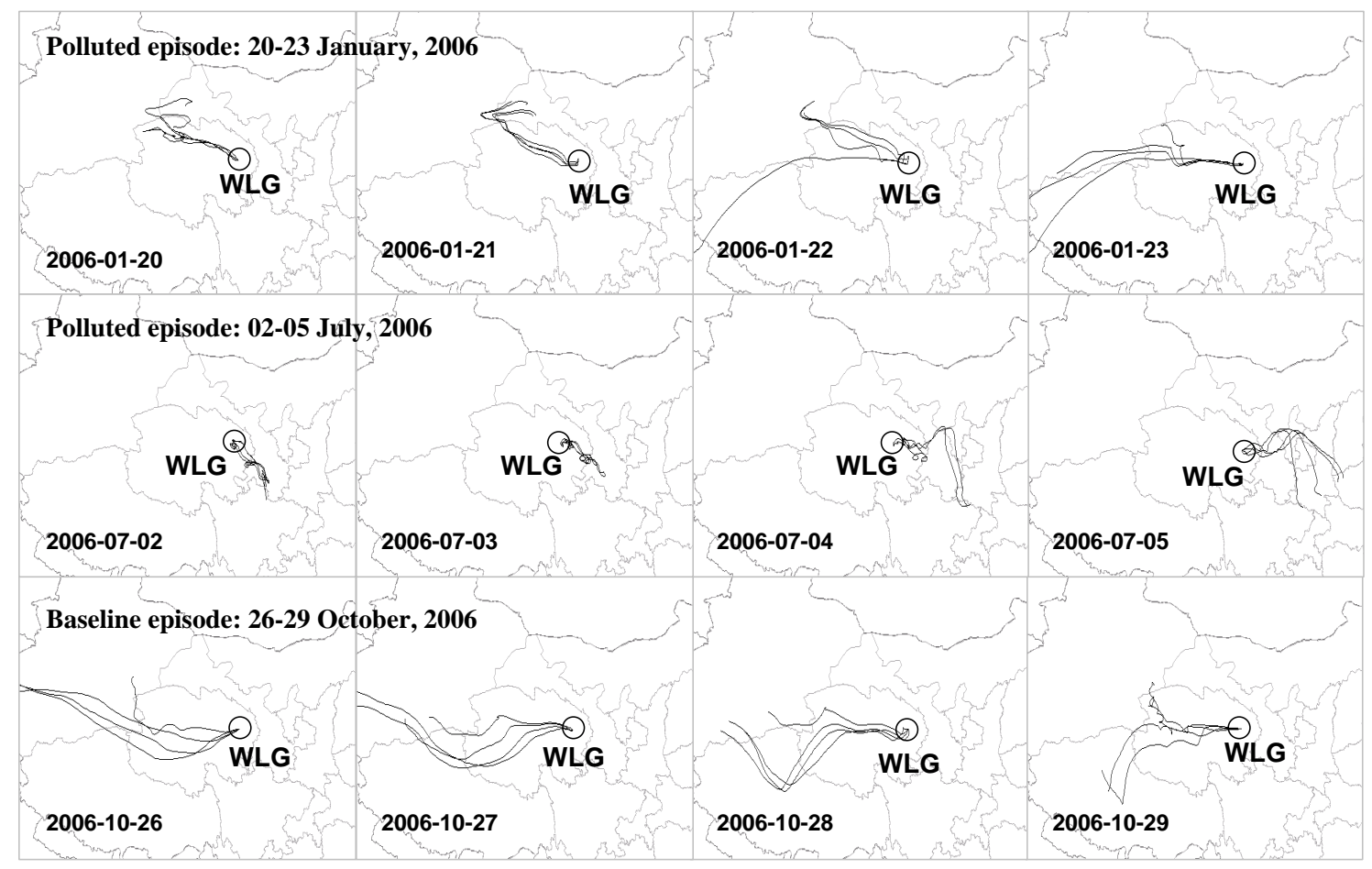

Fig. 8. Trajectories (+500 $\mathrm{m}$ above ground) for selected days (5-d back trajectories at 00:00, 06:00, 12:00 and 18:00 UTC), open circle is the location of WLG; black cross is the location of Geermu city.

by both clean air masses and polluted boundary layer air (Zellweger et al., 2003) and observations at JFJ have been used to assess locations of emissions from the European continent (Reimann et al., 2008). The CO measurements at JFJ were made by a Non-dispersive IR(NDIR) technique performed by Empa as part of the Swiss National Air Pollution Monitoring Network and as a contribution to the GAW programme. The data selection algorithm used to define regional baseline of CO at WLG was also applied to the JFJ data.

The background CO monthly means at WLG exhibited a seasonal cycle typical of the Northern Hemisphere where in the late winter/early spring $\mathrm{CO}$ reaches its annual maximum before a rapid decrease to its summer minimum resulting from reaction with the $\mathrm{OH}$ radical. Similarly, the general characteristics of the CO baseline at WLG are consistent with JFJ and probably may represent regional baseline conditions over the Eurasian continent. While the summer CO mixing ratios at WLG and JFJ are similar, we find larger differences in background CO in winter when JFJ is $20-40 \mathrm{ppb}$ higher, possibly reflecting different surface sources and greater wintertime $\mathrm{OH}$ at WLG.

Pollution episodes at WLG were characterized by significantly enhanced mixing ratios and large and erratic variations. This apparently reflects influence of regional emission sources on WLG. The greatest enhancements above WLG background occur in the winter and spring months due to transport of pollution from the northwest of the site (as

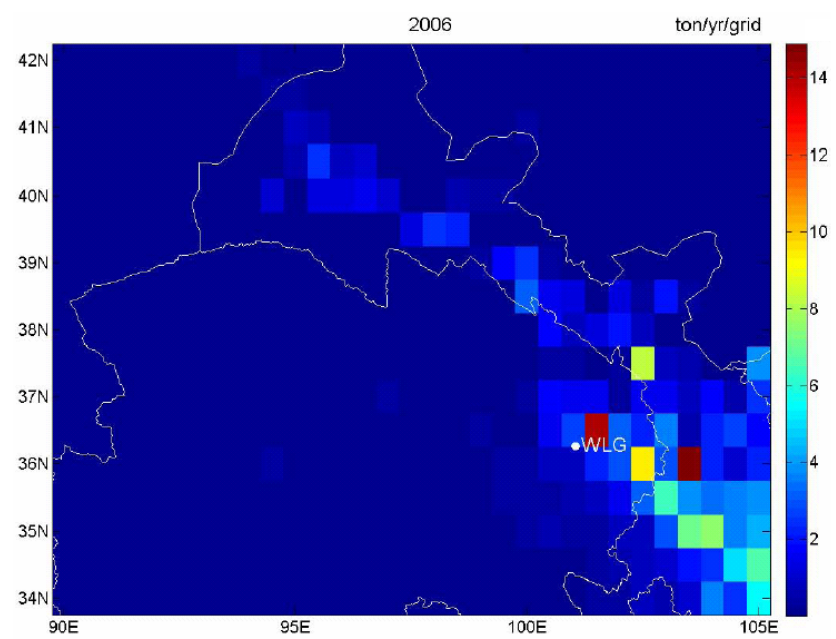

Fig. 9. Total anthropogenic emissions (including biofuels) of CO based on the INTEXB (Intercontinental Chemical Transport Experiment-Phase B) emission inventory for the region around WLG (black dot in the map is location of WLG) (http://www.cgrer. uiowa.edu/EMISSION_DATA_new/data/intex-b_emissions/).

further discussed in Sects. 3.3 and 3.4). The relatively lower enhancements in summer may reflect CO loss during transport. 


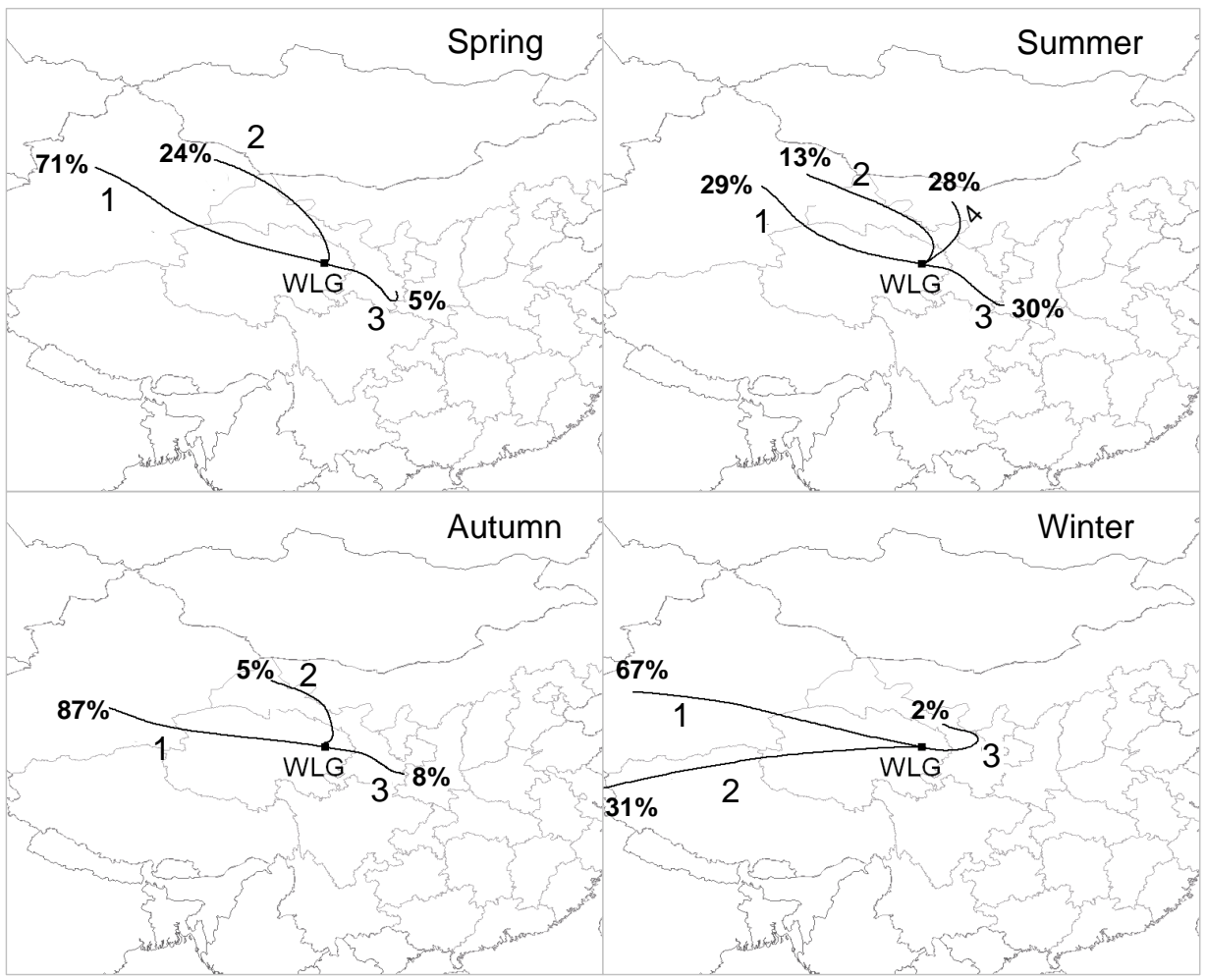

Fig. 10. Isobaric trajectory clusters (+500 m above ground) in spring, summer, autumn and winter at WLG, July 2004-June 2007. Numbers beside each cluster indicate cluster sequence; the percentages present the trajectory counts of the total.

\subsection{Long-distance transport impact on ambient CO}

\subsubsection{Trajectories analysis of selected observation episodes}

Statistical analysis of air mass back trajectories combined with long-term ambient air measurements can be used for analyzing large-scale air pollutant transport and source identification at a receptor site (Stohl, 1996; Rousseau et al., 2004). Trajectory position error of the method is typically considered to be about $20 \%$ of the traversed distance (Stohl, 1998), but the statistical uncertainty can be reduced with large sets of trajectories. In our study, the CO data from July 2004 to June 2007 were analyzed using trajectory statistics. Five day $(120 \mathrm{~h})$ back trajectories originating at 00:00, 06:00, 12:00 and 18:00 UTC were calculated by the Hybrid SingleParticle Lagrangian Integrated Trajectory model (HYSPLIT) (Draxler and Hess, 1998) using NCEP (National Centers for Environmental Prediction) reanalysis data. The arrival height of the trajectories was $500 \mathrm{~m}$ above ground level which has been shown to be the most representative for air sampled at WLG (Zhou et al., 2003, 2004). Figure 7 shows hourly data of ambient $\mathrm{CO}$ for 2006 . Two pollution episodes (2023 January 2006 and 2-5 July 2006) and one baseline period (26-29 October 2006) were selected as examples for evaluating source regions. Figure 8 shows the trajectories for the selected days. The period in October represents background conditions when corresponding trajectories track to the Tibet and south Xinjiang Uygur Autonomous Region (XUAR). The episode of high CO in July is associated with the trajectories from the heavily populated regions east or southeast of WLG suggesting a large source area due to human activities. During the event on 20-23 January 2006, the highest CO values were observed when the trajectories indicated transport of air parcels arrive from the area northwest of WLG and via the Ge'ermu urban area (the second largest city of Qinghai), a major source region due to rapid industrial development caused by abundant petroleum and natural gas resources, additional emissions are expected from biofuel burning in the region.

\subsubsection{Cluster analysis}

Cluster analysis, which combines the trajectories into representative spatial groups using multivariate statistics, was employed to identify distinct transport patterns (Fig. 10). Angle distance was chosen as the clustering criterion (Sirois and Bottenheim, 1995). We used CO hourly averages corresponding to trajectory arrival times at 00:00, 06:00, 12:00 and 18:00 UTC in the analysis. Each trajectory in a cluster used to obtain cluster statistics. Table 3 lists regional characteristics for each cluster by season. 
Table 2. Statistical CO results of clusters in different seasons at WLG.

\begin{tabular}{|c|c|c|c|c|c|c|c|}
\hline & \multirow{2}{*}{ Cluster } & \multicolumn{3}{|c|}{ Background conditions } & \multicolumn{3}{|c|}{ Polluted conditions } \\
\hline & & $\begin{array}{r}\text { Number of } \\
\text { Trajectories (-) }\end{array}$ & $\begin{array}{r}\text { mean }(\mathrm{CO}) \\
(\mathrm{ppb})\end{array}$ & $\begin{array}{r}\text { s.d. }(\mathrm{CO}) \\
(\mathrm{ppb})\end{array}$ & $\begin{array}{r}\text { Number of } \\
\text { Trajectories (-) }\end{array}$ & $\begin{array}{r}\text { mean }(\mathrm{CO}) \\
(\mathrm{ppb})\end{array}$ & $\begin{array}{r}\text { s.d. }(\mathrm{CO}) \\
(\mathrm{ppb})\end{array}$ \\
\hline \multirow{3}{*}{ Spring } & 1 & 202 & 121.8 & 6.2 & 169 & 154.5 & 26.8 \\
\hline & 2 & 26 & 125 & 6.1 & 100 & 177.8 & 33.2 \\
\hline & 3 & 4 & 122.9 & 4.9 & 23 & 183.3 & 38.2 \\
\hline \multirow{4}{*}{ Summer } & 1 & 107 & 107.4 & 7.1 & 61 & 141.3 & 18 \\
\hline & 2 & 21 & 111.3 & 4.8 & 53 & 150.3 & 25.3 \\
\hline & 3 & 16 & 115.9 & 5.4 & 153 & 178.8 & 41.3 \\
\hline & 4 & 40 & 112.9 & 5.3 & 120 & 154.7 & 28 \\
\hline \multirow{3}{*}{ Autumn } & 1 & 281 & 99.2 & 6.4 & 176 & 141.4 & 42.5 \\
\hline & 2 & 10 & 97.2 & 3.4 & 16 & 149.2 & 31.1 \\
\hline & 3 & 2 & 94.8 & 4.3 & 38 & 181.1 & 67.8 \\
\hline \multirow{3}{*}{ Winter } & 1 & 240 & 112.8 & 6.4 & 148 & 183.3 & 75.8 \\
\hline & 2 & 103 & 113.7 & 5.9 & 78 & 181.4 & 68.6 \\
\hline & 3 & 0 & NA & NA & 12 & 206.4 & 65.5 \\
\hline
\end{tabular}

The "Cluster" indicates different air parcel origin/routes (see Fig. 9). The statistical results for background and polluted CO mixing ratios in different seasons are listed here: "Number of Trajectories" refers to quantity of trajectories in each corresponding cluster; "mean(CO)" refers to background or polluted CO mixing ratios; "s.d.(CO)" refers to standard deviation of the background or polluted $\mathrm{CO}$ mixing ratios.

Table 3. Characteristics for each cluster in all seasons.

\begin{tabular}{|c|c|c|c|}
\hline Season & Cluster & Region & Characteristic \\
\hline Spring & $\begin{array}{l}1 \\
2 \\
3\end{array}$ & $\begin{array}{l}\text { central region of XUAR and north of Qinghai province } \\
\text { northwest of Gansu province } \\
\text { southeast of Gansu province }\end{array}$ & $\begin{array}{l}\text { fossil fuel resources and agricultural } \\
\text { rural } \\
\text { populated }\end{array}$ \\
\hline Summer & $\begin{array}{l}1 \\
2 \\
3 \\
4\end{array}$ & $\begin{array}{l}\text { central region of XUAR and northwest of Qinghai province } \\
\text { northwest of Gansu province } \\
\text { southeast of Gansu province } \\
\text { central region of Gansu province }\end{array}$ & $\begin{array}{l}\text { fossil fuel resources and agricultural } \\
\text { rural } \\
\text { populated } \\
\text { rural }\end{array}$ \\
\hline Autumn & $\begin{array}{l}1 \\
2 \\
3\end{array}$ & $\begin{array}{l}\text { northwest of Qinghai and some region of southeast XUAR } \\
\text { northwest of Gansu province } \\
\text { southeast of Gansu province }\end{array}$ & $\begin{array}{l}\text { fossil fuel resources and agricultural } \\
\text { rural } \\
\text { populated }\end{array}$ \\
\hline Winter & $\begin{array}{l}1 \\
2 \\
3\end{array}$ & $\begin{array}{l}\text { central region of XUAR and northwest of Qinghai } \\
\text { northwest of Tibet and Qinghai province (only in this season) } \\
\text { central and southeast of Gansu province }\end{array}$ & $\begin{array}{l}\text { fossil fuel resources and agricultural } \\
\text { undeveloped } \\
\text { populated }\end{array}$ \\
\hline
\end{tabular}

Within each cluster, air parcels transported to WLG are characterized as either background or polluted using the background subtraction method (Table 2). Total anthropogenic $\mathrm{CO}$ annual emissions for the region around WLG (including biofuels) based on the INTEX-B study (Intercontinental Chemical Transport Experiment-Phase B, Zhang et al., 2009) are shown in Fig. 9. Distribution of sources from the REAS (Regional Emission inventory in Asia) shows a similar pattern of higher emissions in the Gansu province and in the industrialized areas to the east of WLG (Ohara et al., 2007) with much lower emissions in the west. In spring, cluster 3 (Fig. 10) contains air parcels mainly from the area southeast of the WLG, $85 \%$ of which is characterized as polluted (Table 2). The air parcels from cluster 2, arriving from the northwest and the Gansu region represent $24 \%$ of the transport, also show elevated CO levels likely reflecting emissions from fossil fuel and biomass combustion. Cluster 1 (with $71 \%$ of the trajectories) corresponds to the air parcels coming from the central region of XUAR and north of the Qinghai province. The relatively remote area defined in cluster 1 has widespread but relatively low emissions from fossil fuel combustion under a growing economy in the 


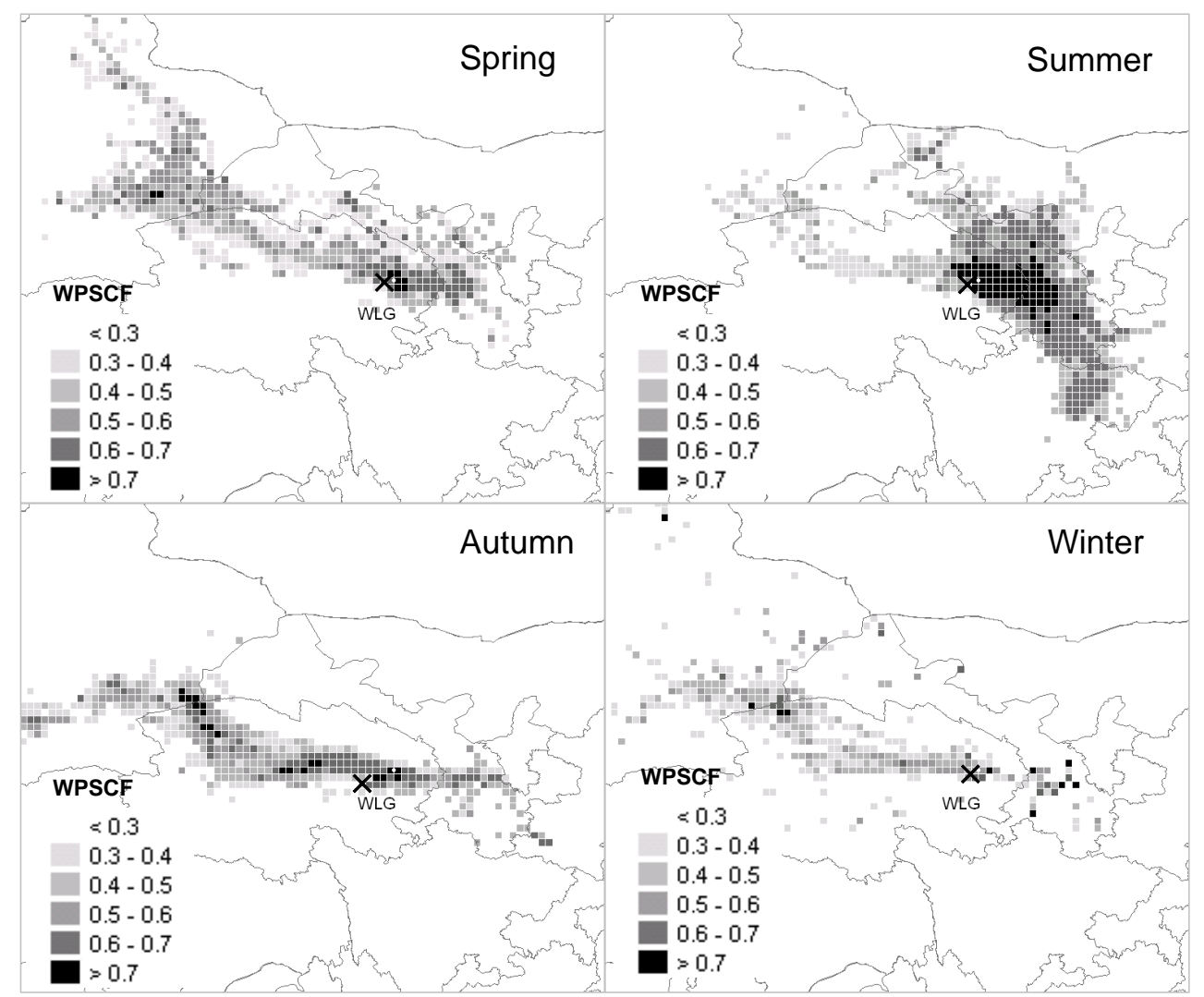

Fig. 11. Potential source regions calculated from trajectory statistics during July 2004-June 2007. WPSCF values have an arbitrary unit, higher vales (e.g. WPSCF $>0.6$, the highest WPSCF should be 1) indicating a higher probability for a grid cell of CO source.

region. Biomass burning of agricultural products may also add to air parcels from the west to enhance $\mathrm{CO}$ mixing ratios (Yan et al., 2006).

In summer, the most elevated $\mathrm{CO}$ mixing ratios are associated with cluster 3 which passed through the urbanized area southeast of WLG (e.g. Lanzhou city, the central region and southeast of Gansu province). Clusters 1 and 2 represent advection from the north or northwest (central region of XUAR and region northwest of Qinghai) with relatively low $\mathrm{CO}$ mixing ratios compared to those observed in cluster 3 , but they still contain a large number of trajectories with enhanced $\mathrm{CO}$ originating in more polluted areas. As in spring, fossil fuel combustion and biomass burning add $\mathrm{CO}$ to this region. However, in summer, unlike other times of the year, WLG is significantly influenced by air masses from the populated southeastern regions. In autumn and winter the high $\mathrm{CO}$ mixing ratios were associated with airflow from the east or southeast. All year round, air parcels originating from this direction exhibit the highest $\mathrm{CO}$ levels.

As seen in spring and summer, during autumn and winter polluted air arrives from the west or northwest. This further indicates that the XUAR region and the north Qinghai province is a potential CO source region, which is also consistent with model estimations (GEOS-CHEM) using biofuel and fossil fuel emissions determined by Yevich and Logan (2003) and Bey et al. (2001) (as reported in Liang et al., 2004). These showed a band of potential source region at the junction of Qinghai, Gansu and XUAR, as well as northwest of Qinghai and central area of XUAR, in agreement with studies having found strong $\mathrm{CO}$ emissions from biofuels especially during cold winters (Yan et al., 2006). The large number of baseline data, which are attributed to air masses originating from the western or a southwestern area (via sparsely inhabited Tibet) suggests a relatively clean environment.

\subsubsection{PSCF analysis}

We also used potential source contribution function analysis (PSCF) for further investigation. PSCF can compute probability density functions reflecting the residence times of an air parcel over a given geographical area prior to its arrival at the measurement site using back trajectories (Ashbaugh et al., 1985; Begum et al., 2005). To calculate the PSCF, the geographic region covered by the trajectories is divided into an array of $0.3 \times 0.3$ degree grid cells (with a height of up to $500 \mathrm{~m}$ from ground). The PSCF is a location function defined by cell indices $i$ and $j$ while the number of trajectories that 
pass through the $i j$-th cell is denoted by $n_{i j}$. The number of trajectories resulting in $\mathrm{CO}$ values that exceed the background value is defined by $m_{i j}$.

The probability that any given cell can be related to enhance $\mathrm{CO}$ is defined as $\mathrm{PSCF}_{i j}=m_{i j} / n_{i j}$ (following Polissar et al., 1999).

This method tends to give good angular but poor radial resolution because the trajectories converge as they approach the receptor (Vasconcelos et al., 1996). Because grid cells always have the same PSCF value regardless of whether $\mathrm{CO}$ mixing ratios were slightly higher or much higher than the threshold, it is difficult to distinguish between relatively moderate and stronger $\mathrm{CO}$ sources. To reduce this effect, PSCF values were weighted with an arbitrary coefficient $W_{i j}$ (Polissar et al., 1999), which reduced them when the total number of the endpoints in a particular cell was less than about three times the average value of the endpoints in each cell. Here $W_{i j}$ was defined as:

$$
W_{i j}= \begin{cases}1.00 & n_{i j}>80 \\ 0.70 & 20<n_{i j} \leq 80 \\ 0.42 & 10<n_{i j} \leq 20 \\ 0.05 & n_{i j} \leq 10\end{cases}
$$

Figure 11 shows the potential source regions resulting from trajectory statistics of $\mathrm{CO}$ in different seasons. Regions in black and white respectively indicate strong and weak potential $\mathrm{CO}$ sources. In general, the $\mathrm{CO}$ source locations identified by PSCF are very similar to the results obtained by the clustering method. In summer, the black and dark gray colored regions (areas more likely to be $\mathrm{CO}$ source areas) showed large spatial extensions to the northeast and southeast of WLG, areas with dense populations and industry. Otherwise, in the other three seasons, the PSCF are very similar and the source regions were mainly situated northwest of WLG, influences which may be increasing especially under the strategy of China's western region development. This policy could significantly change the $\mathrm{CO}$ source distributions in the future. Large increases in regional emissions throughout China will surely have an impact on global CO.

\section{Conclusions}

In this paper, we report a revision to the quasi-continuous observations of CO at WLG to the WMO 2000 scale. The three year record of CO mixing ratios exhibited large fluctuations showing periodic transport of polluted air to the site. We have used a "robust local regression" statistical method to distinguish the background data from polluted air and find that approximately $50 \%$ of all observations can be identified as background air. The seasonal variation of background $\mathrm{CO}$ mixing ratios shows a minimum in summer and a maximum in winter, which is consistent with that observed in the Northern Hemisphere CO surface distribution and the high altitude measurements at JFJ. Larger differences in background $\mathrm{CO}$ between the two sites is found in winter, when $\mathrm{CO}$ at JFJ is $20-40$ ppb higher than at WLG, reflect different surface sources and possibly higher wintertime $\mathrm{OH}$ concentrations at WLG. Compared to the JFJ, air masses identified at WLG as polluted contained more CO relative to the background values and displayed large and irregular fluctuations suggesting greater influence from regional emission sources. By combining the $\mathrm{CO}$ data with trajectory based statistics and cluster analysis, we have demonstrated that air masses originating from the east to the southeast of WLG have the strongest impact on $\mathrm{CO}$, however, are only significant in the summer transport from this direction. In the other seasons, air parcels arriving via the northwest are more common. These exhibit both background and polluted characteristics. Air from the central XUAR and the Ge'ermu urban area have shown enhanced CO levels probably due to the growing economy in western China. In addition, trajectories via northwestern Gansu with high CO levels showed a relatively high anthropogenic emission, which has been demonstrated by comparison with the $\mathrm{CO}$ emission inventory (including biofuels) based on the INTEX-B around WLG. However, the $\mathrm{CO}$ emissions in western China are still very low. Air parcels coming from sparsely populated Tibet contribute least to the enhanced $\mathrm{CO}$ values observed at WLG.

Acknowledgements. This work was supported by National Natural Science Foundation of China (40775078), Non-profit Research Project (Grant No. GYHY200806026) International S\&T Cooperation Program of MOST (Grant No. 2007DFA20650) and National Basic Research Program of China "973" (Grant No. 2010CB950601). The station personnel have extensively supported the operation at WLG station. Yaqiang Wang (CMA/CAMS) is acknowledged for his help with the calculation of trajectories and clustering/PSCF. Xingqin An (CMA/CAMS) and Gabrielle Petron (NOAA/ESRL/GMD) provided maps of $\mathrm{CO}$ emissions in the region near Mt. Waliguan.

Edited by: I. Trebs

\section{References}

Ashbaugh, L. L., Malm, W. C., and Sadeh, W. Z.: A residence time probability analysis of sulfur concentrations at Grand Canyon National Park, Atmos. Environ., 19, 1263-1270, 1985.

Begum, B. A., Kim, E., Jeong, C. H., Lee, D. W., and Hopke, P. K.: Evaluation of the potential source contribution function using the 2002 Quebec forest fire episode, Atmos. Environ., 39, 37193724, 2005.

Bey, I., Jacob, D. J., Yantosca, R. M., Logan, J. A., Field, B. D., Fiore, A. M., Li, Q., Liu, H. Y., Mickley, L. J., and Schultz, M. G.: Global modeling of tropospheric chemistry with assimilated meteorology: model description and evaluation, J. Geophys. Res., 106, 23073-23096, 2001.

Daniel, J. S. and Solomon, S.: On the climate forcing of carbon monoxide, J. Geophys. Res., 103, 13249-13260, 1998. 
Draxler, R. R. and Hess, G. D.: An overview of the HYSPLIT 4 modeling system for trajectories, dispersion, and deposition, Aust. Meteorol. Mag., 47, 295-308, 1998.

Holloway, T., Levy II, H., and Kasibhatla, P.: Global distribution of carbon monoxide, J. Geophys. Res., 105, 12123-12147, 2000.

Liang, Q., Jaegl' e, L., Jaffe, D. A., Weiss-Penzias, P., Heckman, A., and Snow, J. A.: Longrange transport of Asian pollution to the Northeast Pacific: seasonal variations and transport pathways of carbon monoxide, J. Geophys. Res., 109, D23S07, doi:10.1029/2003JD004402, 2004.

Logan, J. A., Prather, M. J., Wofsy, S. C., and McElroy, M. B.: Tropospheric chemistry: a global perspective, J. Geophys. Res., 86, 7210-7254, 1981.

Novelli, P. C., Steele, L. P., and Tans, P. P.: Mixing ratios of carbon monoxide in the troposphere, J. Geophys. Res., 102, 1285512861, 1992.

Novelli, P. C., Collins Jr., J. E., Myers, R. C., Sachse, G. W., and Scheel, H. E.: Re-evaluation of NOAA/CMDL carbon monoxide reference scale and comparisons with $\mathrm{CO}$ reference gases at NASA-Langley and the Fraunhofer Institute, J. Geophys. Res., 99, 12833-12839, 1994a.

Novelli, P. C., Masarie, K. A., Tans, P. P., and Lang, P. M.: Recent changes in atmospheric carbon monoxide, Science, 263, 15871590, 1994b.

Novelli, P. C., Masarie, K. A. and Lang, P. M.: Distributions and recent changes of carbon monoxide in the lower troposphere, J. Geophys. Res., 103, 19015-19033, 1998.

Novelli, P. C., Masarie, K. A., Lang, P. M., Hall, B. D., Myers, R. C., and Elkins, J. W.: Reanalysis of tropospheric CO trends: Effects of the 1997, 1998 wildfires, J. Geophys. Res., 108(D15), 4464-4477, doi:10.1029/2002JD003031, 2003.

Ohara, T., Akimoto, H., Kurokawa, J., Horii, N., Yamaji, K., Yan, X., and Hayasaka, T.: An Asian emission inventory of anthropogenic emission sources for the period 19802020, Atmos. Chem. Phys., 7, 4419-4444, doi:10.5194/acp-7-4419-2007, 2007.

Polissar, A. V., Hopke, P. K., Paatero, P., Kaufmann, Y. J., Hall, D. K., Bodhaine, B. A., Dutton, E. G., and Harris, J. M.: The aerosol at Barrow, Alaska: long-term trends and source locations, Atmos. Environ., 33, 2441-2458, 1999.

Reimann, S., Vollmer, M. K., Folini, D., Steinbacher, M., Hill, M., Buchmann, B., Zander, R., and Mahieu, E.: Observations of long-lived anthropogenic halocarbons at the highAlpine site of Jungfraujoch (Switzerland) for assessment of trends and European sources, Sci. Total Environ., 391, 224-231, doi:10.1016/j.scitotenv.2007.10.022, 2008.

Rousseau, D. D., Duzer, D., Etienne, J. L., Cambon, G., Jolly, D., Ferrier, J., and Schevin, P.: Pollen record of rapidly changing air trajectories to the North Pole, J. Geophys. Res., 109, D06116, doi:10.1029/2003JD003985, 2004.

Ruckstuhl, A. F., Matthew, P. J., Robert, W. F., and James. A. D.: Baseline subtraction using robust local regression estimation, J. Quant. Spectrosc. Ra., 68, 179-193, 2001.

Ruckstuhl, A. F., Henne, S., Reimann, S., Steinbacher, M., Buchmann, B., and Hueglin, C.: Robust extraction of baseline signal of atmospheric trace species using local regression, Atmos. Meas. Tech. Discuss., 3, 5589-5612, doi:10.5194/amtd-3-55892010, 2010.

Sirois, A. and Bottenheim, J. W.: Use of backward trajectories to interpret the 5-year record of PAN and $\mathrm{O}_{3}$ ambient air concentrations at Kejimkujik National Park, Nova Scotia, J. Geophys. Res., 100, 2867-2881, 1995.

Stohl, A.: Trajectory statistics -a new method to establish sourcereceptor relationships of air pollutants and its application to the transport of particulate sulfate in Europe, Atmos. Environ., 30, 579-587, 1996.

Stohl, A.: Computation, accuracy and applications of trajectories a review and bibliography, Atmos. Environ., 32, 947-966, 1998.

Thompson, A. M.: The oxidizing capacity of the Earth's atmosphere: probable past and future changes, Science, 256, 11571168, 1992.

Vasconcelos, L. A. P., Kahl, J. D. W., Liu, D., Macias, E. S., and White, W. H.: Spatial resolution of a transport inversion technique, J. Geophys. Res., 101, 19337-19342, 1996.

WMO: Guidelines for the Measurement of Atmospheric Carbon Monoxide, GAW Report No. 192, World Meteorological Organization, Geneva, Switzerland, 2010.

Yan, X. Y., Ohara, T., and Akimoto, H.: Bottom-up estimate of biomass burning in mainland China, Atmos. Environ., 40, 52625273, 2006.

Yevich, R. and Logan, J. A.: An assessment of biofuel use and burning of agricultural waste in the developing world, Global Biogeochem. Cy., 17, 1095, doi:10.1029/2002GB001952, 2003.

Zellweger, C., Hofer, P., and Buchmann, B.: System and Performance Audit of Surface Ozone and Carbon Monoxide at the China GAW Baseline Observatory Waliguan Mountain, WCCEmpa Report 00/3, available at: http://www.empa.ch/plugin/ template/empa/*/7571 (last access: September 2000), 2000.

Zellweger, C., Forrer, J., Hofer, P., Nyeki, S., Schwarzenbach, B., Weingartner, E., Ammann, M., and Baltensperger, U.: Partitioning of reactive nitrogen $\left(\mathrm{NO}_{\mathrm{y}}\right)$ and dependence on meteorological conditions in the lower free troposphere, Atmos. Chem. Phys., 3, 779-796, doi:10.5194/acp-3-779-2003, 2003.

Zellweger, C., Klausen, J., and Buchmann, B.: System and Performance Audit of Surface Ozone Carbon Monoxide and Methane at the Global GAW Station Mt. Waliguan, China, October 2004, WCC-Empa Report 04/3, available at: http://www.empa.ch/ plugin/template/empa/*/7571 (last access: October 2004), 2004.

Zellweger, C., Hüglin, C., Klausen, J., Steinbacher, M., Vollmer, M., and Buchmann, B.: Inter-comparison of four different carbon monoxide measurement techniques and evaluation of the long-term carbon monoxide time series of Jungfraujoch, Atmos. Chem. Phys., 9, 3491-3503, doi:10.5194/acp-9-3491-2009, 2009.

Zhang, Q., Streets, D. G., Carmichael, G. R., He, K. B., Huo, H., Kannari, A., Klimont, Z., Park, I. S., Reddy, S., Fu, J. S., Chen, D., Duan, L., Lei, Y., Wang, L. T., and Yao, Z. L.: Asian emissions in 2006 for the NASA INTEX-B mission, Atmos. Chem. Phys., 9, 5131-5153, doi:10.5194/acp-9-5131-2009, 2009.

Zhou L. X., Tang J., Ernst, M. K., and Worthy, D. E.: Continuous measurement of baseline atmospheric carbon monoxide in western China. Environ. Sci., 22, 1-5, 2001 (in Chinese with English abstract).

Zhou, L. X., Tang, J., Wen, Y. P., Li, J. L., Yan, P., and Zhang, X. C.: The impact of local winds and long-range transport on the continuous carbon dioxide record at Mount Waliguan, China, Tellus B, 55, 145-158, 2003.

Zhou, L. X., Worthy, D. E., Lang, J. P. M., Ernst, M. K., Zhang, X. 
C., Wen, Y. P., and Li, J. L.: Ten years of atmospheric methane observations at a high elevation site in Western China, Atmos. Environ., 38, 7041-7054, 2004.

Zhou, L. X., Conway, T. J., White, J. W. C., Mukai, H., Zhang, X., Wen, Y., Li, J., and Mac-Clune, K.: Long-term record of atmospheric $\mathrm{CO}_{2}$ and stable isotopic ratios at Waliguan Observatory: background features and possible drivers, 1991-2002, Global Biogeochem. Cy., 19, GB3021, doi:10.1029/2004GB002430, 2005 .
Zhou, L. X., White, J. W. C., Conway, T. J., Mukai, H., MacClune, K., Zhang, X., Wen, Y., and Li, J.: Long-term record of atmospheric $\mathrm{CO}_{2}$ and stable isotopic ratios at Waliguan $\mathrm{Ob}$ servatory: seasonally averaged 1991-2002 source/sink signals, and a comparison of 1998-2002 record to the 11 selected sites in the Northern Hemisphere, Global Biogeochem. Cy. 20, GB2001, doi:10.1029/2004GB002431, 2006. 